\title{
Survival and Predictors of Mortality among Adults on Antiretroviral Therapy in Selected Public Hospitals in Harar, Eastern Ethiopia
}

\author{
Tesfaye Digaffe*, Berhanu Seyoum and Lamessa Oljirra
}

College of Health and Medical Sciences; Haramaya University, P.O.Box:235, Haramaya, Ethioipia

\begin{abstract}
In resource-poor countries, access to ART has improved during the last years and mortality rates among treated patients have declined substantially. However, compared to patients in high-income countries, patients in resourcepoor countries are at higher risk of death in the early months of treatment. To avoid such early deaths, the identification of possible risk factors and potential causes of deaths are important. A retrospective cohort study was conducted among a cohort of 655 People Living with HIVIAIDS (PLWHA) on ART in three in selected public hospitals in Harar, Eastern Ethiopia. From the total PLWHA participants, $438(66.9 \%)$ were female and the median age of patients were 33 years. The median follow-up period was 38 months. During the follow up period, 74 (11.4\%) patients were deceased. The cohort was followed for 1913 Person-Years of observation. Total mortality rate over the follow up period was 3.9 per 100 person-years. Most of deaths ( $n=36,49 \%)$ occurred in the first 3 months of ART initiation. Three baseline factors could be independently identified: World Health Organization (WHO) clinical stage III and IV (Hazard Ratio $(\mathrm{HR})=2.13)$, $\mathrm{CD} 4$ counts lower than $50 \mathrm{cells} / \mu \mathrm{l}(\mathrm{HR}=2.34)$, not taking base line Cotrimoxazole Prophylaxis Treatment (CPT) $(H R=2.46)$. Despite optimizing ART delivery in Ethiopia, a proportion of early deaths among patients with very advanced disease are not likely to be preventable with ART. This may require extensive and detailed study in resource poor countries. Thus, a more fundamental issue and the greater challenge is the need for early HIV diagnosis and provision of appropriate longitudinal HIV care prior to ART eligibility.
\end{abstract}

Keywords: Mortality; Survival; CD4 cell count; Anti-retroviral treatment

\section{Introduction}

Human Immunodeficiency Virus (HIV) is the world's leading infectious killer, with an estimated 2 million Acquired ImmunoDeficiency Syndrome (AIDS) deaths occurring in 2008 alone. At the end of 2008, an estimated 33.4 million people worldwide were living with HIV. That same year, some 2.7 million people became newly infected with the virus. More than $95 \%$ of all HIV-positive people are in low- and middle-income countries [1].

Most resource-limited countries have embarked on national antiretroviral programs to treat as many HIV positive individuals as possible. The implementation of these programs, in resourcelimited settings is based on a public health approach that delivers comprehensive HIV care. These strategies maximizes the survival of HIV infected persons through standardized sequencing of available ARVs delivered to individuals through simplified approaches supported by clinical and basic laboratory monitoring [2].

The sharp increase in ART uptake in 2006 has been largely due to the rapid increase in the provision of free treatment at more sites. The marked variation in ART utilization patterns between urban and rural communities and among zones and regions requires further studies. Recommendations are made for further expansion and sustainability of the ART scale-ups [3]. The clinical benefit of ART for AIDS patients, in terms of mortality reduction and improved quality of life, is well established but shows regional variations, with higher case fatality rates in poor countries [4]

In resource-poor countries, access to ART has improved during the last years and mortality rates among treated patients have declined substantially [5]. However, compared to patients in high-income countries, patients in resource-poor countries are at higher risk of death in the early months of treatment. To avoid such early deaths, the identification of possible risk factors and potential causes of deaths are important [6].

A few years back, Ethiopia planned for a large-scale ART programme. Hence, Successful implementation of such initiatives needs scientific evidence generated in the appropriate settings [7].

\section{Objectives}

\section{General objective}

To analyze the survival and predictors of mortality in a cohort of People Living with HIV/AIDS (PLWHA) on ART in selected public hospitals, Harari region, Eastern Ethiopia.

\section{Specific objectives}

1. To assess the survival pattern of patients on antiretroviral treatment.

2. To determine baseline correlates of survival such as patient demographics, baseline CD4 count, WHO clinical stage, and hemoglobin level.

3. To assess progressive six monthly CD4 cell counts and weight changes during the entire period of follow-up.

*Corresponding author: Tesfaye Digaffe, Haramaya University, College of Health and Medical Sciences, P. O. Box: 235, Haramaya, Ethiopia, Tel: +251-254-660031; E-mail: tdigaffe@yahoo.com

Received April 04, 2014; Accepted September 27, 2014; Published October 03 , 2014

Citation: Digaffe T, Seyoum B, Oljirra L (2014) Survival and Predictors of Mortality among Adults on Antiretroviral Therapy in Selected Public Hospitals in Harar Eastern Ethiopia. J Trop Dis 2: 148. doi: 10.4172/2329-891X.1000148

Copyright: ( 2014 Digaffe T, et al. This is an open-access article distributed unde the terms of the Creative Commons Attribution License, which permits unrestricted use, distribution, and reproduction in any medium, provided the original author and source are credited. 
Citation: Digaffe T, Seyoum B, Oljirra L (2014) Survival and Predictors of Mortality among Adults on Antiretroviral Therapy in Selected Public Hospitals in Harar, Eastern Ethiopia. J Trop Dis 2: 148. doi: 10.4172/2329-891X.1000148

Page 2 of 7

\section{Methods}

\section{Study area and period}

This study was conducted in three selected public hospitals in Harar town. Hiwot Fana University Specialized Hospital, Jugol Hospital, and Harar Tb Hospital are the name of the hospitals where the study was conducted. The data was collected from January, 2010 to March, 2011.

\section{Study design}

A retrospective cohort study was conducted.

\section{Population}

Source of population: All adults living with HIV /AIDS and who started antiretroviral therapy in Harar town public hospitals.

Study population: All adults (age $>14$ years) PLWHA who attended the selected three ART centers. Particularly, patients who started treatment between September 11, 2005 and September 10, 2008 were included in the study.

Sample size determination: sample size was determined by taking the proportion of the mortality rate among PLWHA stage IV (exposed) was $30 \%\left(\mathrm{P}_{1}=0.30\right)$ and among stages II-III (non-exposed) was $20 \%\left(\mathrm{P}_{2}=0.20\right)$ at about one and half year of follow-up period. These proportions were taken from a study conducted in Arba Minch, Southern Ethiopia [6]. By considering $30 \%$ loss to follow-up and effect size of 1.5 ; the final sample size was 651 .

\section{Study variables}

Independent variables: Socio-demographic characteristics and base line clinical, laboratory and ART information,

Dependent variables: The main outcome measure was cumulative survival rates from the initiation of antiretroviral therapy (ART) to the end of follow-up period.

\section{Sampling technique}

A cohort of antiretroviral naïve (an individual who has not been on antiretroviral therapy for treatment of HIV infection) patients who were initiated on treatment from September 11, 2005 to September 10, 2008 from the aforementioned three hospitals were included in the study.
The Inclusion criteria:

- HIV infected patients $>14$ years of age,

- Naïve to antiretroviral therapy before September 11, 2005,

- Received ART on, at least, two clinical visits after initiation of treatment, and

- Not pregnant women.

Exclusion Criteria:

- Patients started ART in other places, and

- Patients without baseline CD4 count and basic personal information.

A total of 1898 PLWHA were obtainable from the three ART clinics that started ART in the accrual period. Four hundred forty five individuals did not fulfill the inclusion criteria and, therefore, excluded from the study (Figure 1).

Data collection method and instruments used: Data were extracted from medical records using the available standard national registers adopted by the Federal Ministry of Health (FMoH). The data were collected by three ART trained nurses. Patients, who lost to follow up, transferred out, stop treatment, and on treatment at the end of the study period were censored.

The distinguishing features of survival data was that at the end of the follow up period the event was probably not have occurred for all patients (event free). For these patients the survival time was said to be censored, indicating that the observation period was cut off before the event occurred. We did not know when the patient would experience the event. Censoring might also occur in other ways. Patients might be lost to follow up during the study period which made further follow up impossible. Therefore, patients who lost to follow up and who met the below listed criteria were censored and included in the data analysis. The patient was censored in the date of any of the following events whichever came first at the end of the follow up period:

I. If the patient is transferred out to other place; the date of transfer,

II. If the patient is lost to follow up; the first appointment date he missed to visit the clinic,

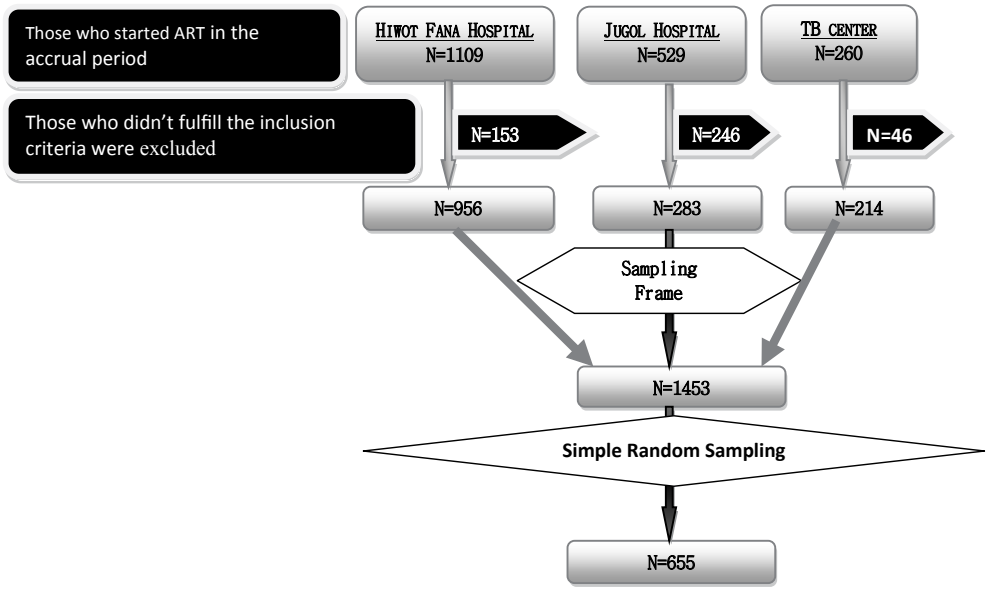

Figure 1: Inclusion of study participants in the cohort for final analysis, in Harar town, Eastern Ethiopia, March 2011. 
Citation: Digaffe T, Seyoum B, Oljirra L (2014) Survival and Predictors of Mortality among Adults on Antiretroviral Therapy in Selected Public Hospitals in Harar, Eastern Ethiopia. J Trop Dis 2: 148. doi: 10.4172/2329-891X.1000148

III. If the patient stops the treatment, the last date of drug resupplies, and

IV. If the patient is alive and on treatment at the end of the followup period, August 10, 2010; the date he/she completed the follow up period.

Data quality control: The collected data were checked for completeness and records with incomplete basic information excluded from the entry. The overall activities were controlled by the principal investigator.
Data analysis: In this study, the main outcome variable was death related to HIV/AIDS and its time of occurrence before the termination of the study. The second outcome variable was time when a patient was lost to follow up and transferred out to other places. In addition, the progressive 6 monthly CD4 and weight changes were other outcome variables that will be used in the analysis.

The survival time was calculated in months using the time interval between the date of ART initiation and (1) date of event (death) for events, (2) date of transfer for transferred out, (3) first date of the first missed appointment for lost cases, (4) the date of drug resupply for

\begin{tabular}{|c|c|c|c|c|c|c|}
\hline Characteristics & $n$ & $n / N(\%)$ & $\begin{array}{c}\text { Active } \\
n(\%)\end{array}$ & $\begin{array}{c}\text { Deceased } \\
n(\%)\end{array}$ & $\begin{array}{l}\text { LTFU } \\
n(\%)\end{array}$ & $\begin{array}{c}\text { TO } \\
n(\%)\end{array}$ \\
\hline $\begin{array}{l}\text { Health Facility } \\
\text { Hiwot Fana Hospital } \\
\text { Jugol Hospital } \\
\text { Tb Center }\end{array}$ & $\begin{array}{l}380 \\
127 \\
148\end{array}$ & $\begin{array}{l}58.0 \\
19.4 \\
22.6\end{array}$ & $\begin{array}{c}296(79.9) \\
90(70.9) \\
109(73.6)\end{array}$ & $\begin{array}{c}28(7.4) \\
27(21.3) \\
18(12.2)\end{array}$ & $\begin{array}{c}16(4.2) \\
7(5.5) \\
11(7.4)\end{array}$ & $\begin{array}{c}40(10.5) \\
3(2.4) \\
10(6.8)\end{array}$ \\
\hline $\begin{array}{l}\text { Sex } \\
\quad \text { Female } \\
\text { Male }\end{array}$ & $\begin{array}{l}438 \\
217\end{array}$ & $\begin{array}{l}66.9 \\
33.1\end{array}$ & $\begin{array}{l}337(76.9) \\
158(72.8)\end{array}$ & $\begin{array}{l}49(112) \\
24(11.1)\end{array}$ & $\begin{array}{l}23(5.3) \\
11(5.1)\end{array}$ & $\begin{array}{c}29(6.8) \\
24(11.1)\end{array}$ \\
\hline $\begin{array}{l}\text { Age in years } \\
\quad 14-24 \\
25-34 \\
35-45 \\
\geq 45\end{array}$ & $\begin{array}{c}47 \\
308 \\
197 \\
103\end{array}$ & $\begin{array}{c}7.2 \\
47.0 \\
30.1 \\
15.7\end{array}$ & $\begin{array}{c}33(70.2) \\
238(77.3) \\
144(73.1) \\
80(77.7)\end{array}$ & $\begin{array}{l}7(14.9) \\
32(10.4) \\
21(10.7) \\
13(12.6)\end{array}$ & $\begin{array}{c}5(10.6) \\
14(4.5) \\
12(6.1) \\
3(2.9)\end{array}$ & $\begin{array}{c}2(4.3) \\
24(7.8) \\
20(10.2) \\
7(6.8)\end{array}$ \\
\hline $\begin{array}{l}\text { Religion } \\
\text { Muslim } \\
\text { Orthodox } \\
\text { Protestant } \\
\text { Catholic }\end{array}$ & $\begin{array}{c}140 \\
442 \\
69 \\
4\end{array}$ & $\begin{array}{c}21.4 \\
67.5 \\
10.5 \\
0.6\end{array}$ & $\begin{array}{c}104(74.3) \\
331(74.9) \\
58(84.1) \\
2(50.0)\end{array}$ & $\begin{array}{c}15(10.7) \\
52(11.8) \\
6(8.7) \\
-\end{array}$ & $\begin{array}{c}9(6.4) \\
23(5.2) \\
1(1.4) \\
1(25)\end{array}$ & $\begin{array}{c}12(8.6) \\
36(8.1) \\
4(5.8) \\
1(25)\end{array}$ \\
\hline $\begin{array}{l}\text { Educational Status } \\
\text { No education } \\
\text { Primary Education } \\
\text { Secondary Education } \\
\text { Tertiary Education }\end{array}$ & $\begin{array}{c}105 \\
271 \\
227 \\
52\end{array}$ & $\begin{array}{c}16.0 \\
41.4 \\
34.7 \\
7.9\end{array}$ & $\begin{array}{c}85(81.0) \\
191(70.5) \\
179(78.9) \\
40(76.9)\end{array}$ & $\begin{array}{c}8(7.6) \\
40(14.8) \\
24(10.6) \\
1(1.9)\end{array}$ & $\begin{array}{l}7(6.7) \\
14(5.2) \\
7(3.1) \\
6(11.5)\end{array}$ & $\begin{array}{c}5(4.8) \\
26(9.6) \\
17(7.5) \\
5(9.6)\end{array}$ \\
\hline Characteristics & $n$ & $n / N(\%)$ & $\begin{array}{c}\text { Active } \\
n(\%)\end{array}$ & $\begin{array}{c}\text { Deceased } \\
n(\%)\end{array}$ & $\begin{array}{l}\text { LTFU } \\
n(\%)\end{array}$ & $\begin{array}{c}\text { TO } \\
n(\%)\end{array}$ \\
\hline $\begin{array}{l}\text { Marital Status } \\
\text { Never Married } \\
\text { Married } \\
\text { Separated } \\
\text { Divorced } \\
\text { Widowed }\end{array}$ & $\begin{array}{c}99 \\
296 \\
112 \\
58 \\
90\end{array}$ & $\begin{array}{c}15.1 \\
45.2 \\
17.1 \\
8.9 \\
13.7\end{array}$ & $\begin{array}{l}72(72.7) \\
224(75.7) \\
81(72.3) \\
43(74.1) \\
75(83.3)\end{array}$ & $\begin{array}{l}7(7.1) \\
31(10.5) \\
18(16.1) \\
7(12.1) \\
10(11.1)\end{array}$ & $\begin{array}{c}4(4) \\
18(6.1) \\
6(5.4) \\
3(5.2) \\
3(3.3)\end{array}$ & $\begin{array}{l}16(16.2) \\
23(7.8) \\
7(6.2) \\
5(8.6) \\
2(2.2)\end{array}$ \\
\hline $\begin{array}{l}\text { WHO clinical Stage } \\
\text { Stage I } \\
\text { Stage II } \\
\text { Stage III } \\
\text { Stage IV }\end{array}$ & $\begin{array}{c}44 \\
204 \\
322 \\
85\end{array}$ & $\begin{array}{l}6.7 \\
31.1 \\
49.2 \\
13.0\end{array}$ & $\begin{array}{c}35(79.5) \\
164(80.4) \\
238(73.9) \\
58(68.2)\end{array}$ & $\begin{array}{c}1(2.3) \\
13(6.4) \\
37(11.5) \\
22(25.9)\end{array}$ & $\begin{array}{c}4(9.1) \\
11(5.4) \\
17(5.3) \\
2(2.4)\end{array}$ & $\begin{array}{c}4(9.1) \\
16(7.8) \\
30(9.3) \\
3(3.5)\end{array}$ \\
\hline \begin{tabular}{|c|} 
Functional status \\
Working \\
Ambulatory \\
Bed ridden \\
\end{tabular} & $\begin{array}{c}457 \\
159 \\
39\end{array}$ & $\begin{array}{c}69.8 \\
24.3 \\
6.0\end{array}$ & $\begin{array}{c}352(77) \\
124(78) \\
19(48.7)\end{array}$ & $\begin{array}{c}37(8.1) \\
19(11.9) \\
17(43.6)\end{array}$ & $\begin{array}{l}27(5.9) \\
6(3.8) \\
1(2.6)\end{array}$ & $\begin{array}{c}41(9.0) \\
10(6.3) \\
2(5.1)\end{array}$ \\
\hline 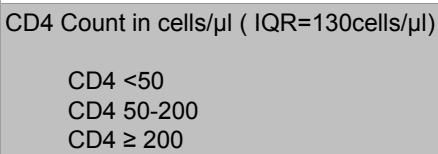 & $\begin{array}{c}94 \\
423 \\
138\end{array}$ & $\begin{array}{l}14.4 \\
64.6 \\
21.0\end{array}$ & $\begin{array}{c}65(69.1) \\
319(75.4) \\
111(80.4)\end{array}$ & $\begin{array}{c}22(23.4) \\
40(9.5) \\
11(8.0)\end{array}$ & $\begin{array}{c}1(1.1) \\
27(6.4) \\
6(4.3)\end{array}$ & $\begin{array}{c}6(6.4) \\
37(8.7) \\
10(7.2))\end{array}$ \\
\hline $\begin{array}{c}\text { BMI in } \mathrm{kg} / \mathrm{m} 2 \quad\left(\mathrm{IQR}=19.1 \mathrm{Kg} / \mathrm{m}^{2}\right) \\
\\
\mathrm{BMI}<18.5 \\
\mathrm{BMI} \geq 18.5 \\
\text { Unknown BMI }\end{array}$ & $\begin{array}{l}131 \\
194 \\
330\end{array}$ & $\begin{array}{l}20.0 \\
29.6 \\
50.4\end{array}$ & $\begin{array}{l}106(80.9) \\
166(85.6) \\
223(67.6)\end{array}$ & $\begin{array}{c}12(9.2) \\
6(3.1) \\
55(16.7)\end{array}$ & $\begin{array}{c}6(4.6) \\
8(4.1) \\
55(16.7)\end{array}$ & $\begin{array}{c}7(5.3) \\
14(7.2) \\
20(6.1)\end{array}$ \\
\hline $\begin{array}{l}\text { Hemoglobin in gm/dl } \quad(\mathrm{IQR}=11.5 \mathrm{~g} / \mathrm{dl}) \\
\mathrm{Hgb}<10 \\
\mathrm{Hgb} \geq 10 \\
\text { Unknown Hgb }\end{array}$ & $\begin{array}{c}92 \\
254 \\
309\end{array}$ & $\begin{array}{l}14.0 \\
38.8 \\
47.2\end{array}$ & $\begin{array}{c}59(64.1) \\
199(78.3) \\
237(76.7)\end{array}$ & $\begin{array}{c}17(18.5) \\
23(9.1) \\
33(10.7)\end{array}$ & $\begin{array}{c}7(7.6) \\
11(4.3) \\
16(5.2)\end{array}$ & $\begin{array}{c}9(9.8) \\
21(8.3) \\
23(7.4)\end{array}$ \\
\hline
\end{tabular}

LTFU: Lost to Follow-Up; TO: Transfer Out

Table 1: Patients' Baseline Socio-Demographic and clinical Characteristics $(N=655)$, in Harar town, Eastern Ethiopia, March 2011. 


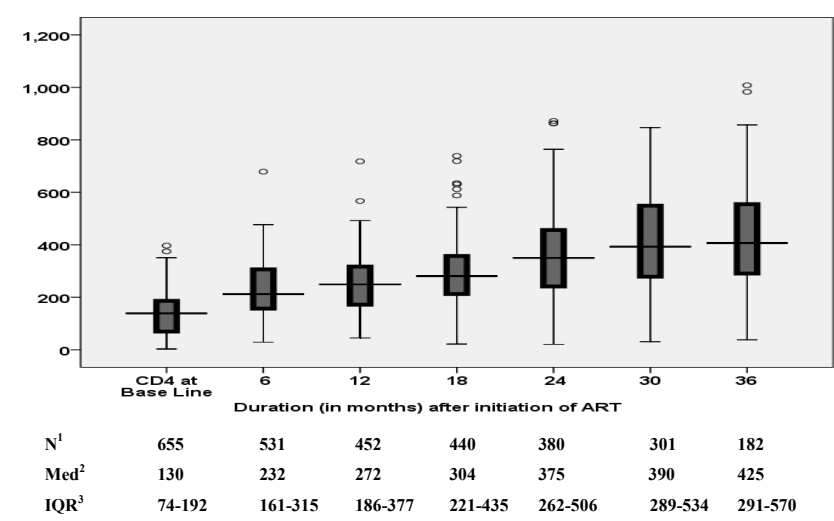

Number of patients, $\quad{ }^{2}$ Median CD4 count. $\quad{ }^{3}$ Inter Quartile RangeFigure Figure 2: Three

Figure 2: Three years of median change in distribution of CD4 Count in six monthly pattern after initiation of ART among PLWHA, , in Harar town, Eastern Ethiopia, March 2011.

those who stop the treatment, and (5) the date in which the patient completed the follow up period.

Kaplan-Meier and Cox-proportional hazard techniques were used to identify predictors of death. That is, Kaplan-Meier model was used to estimate survival probability after ART initiation and log rank tests were used to compare survival curves. Whereas, Bivariate Cox-proportional Hazards model was used to assess the relationship between baseline variables, mortality and to calculate the hazard ratios. The baseline variables included in the analysis were sex, age, marital status, education, WHO stage, baseline CD4 count, baseline body weight, hemoglobin, treatment regimen type and CPT initiation. Variables statistically significant $(\mathrm{p}<0.05)$ in the Bivariate analysis were subsequently tested with multivariate analysis. All statistical tests were two sided and $\mathrm{p}<0.05$ was considered as significant level of association.

Ethical consideration: Ethical clearance was obtained from Institutional Research Ethics Review Committee of Harar Compass, Haramaya University. The patients' information was collected from their charts and ART registers by ART nurses at the respective hospitals. No information that identifies individual patients was used.

\section{Results}

\section{Base line demographic characteristics}

A total of 655 adult PLWHA who were naïve to ART and started ART between September 11, 2005 and September 10, 2008 were included in the study cohort. Basic baseline data were further reviewed for additional two years retrospectively. The age of the patients ranges from 17 to 78 years of age with a median age of 33 years (IQR=2840 years) at the time of ART initiation. Of the total patients included in the study, 438 (66.9\%) were female and the remaining $217(33.1 \%)$ were male. The median follow-up period was 38 months (IQR=27-48). Hiwot Fana University Hospital, Harar TB Center, and Jugol Hospital ART clinics were used to recruit the patients. Three hundred eighty (58\%), 148 (22.6\%), and 127 (19.4\%) patients were recruited from Hiwot Fana, Hrar TB Center, and Jugol Hospitals, respectively. (Table 1)

\section{Clinical and Immunological changes during the follow up} period

Six hundred fifty five patients were followed for the median follow up period of 38 months (IQR=28-47). Seventy four (11.3\%), 53(8.1\%), and $33(5.0 \%)$ patients had died, transferred out, and lost to follow-up, respectively. The base line median CD 4 count was increased by 295 cell/ $\mu \mathrm{l}$ from 130 cells/ $\mu \mathrm{l}(\mathrm{IQR}=74-192)$ to $425(\mathrm{IQR}=291-570)$ after three years of ART initiation (Figure 2). Correspondingly, Base line CD4 cell count had a significant difference from recent CD4 count of 349 cells/ $\mu \mathrm{l}$ $(\mathrm{IQR}=222-493)$ with Wilcoxon Signed-Rank test $(\mathrm{p}<0.001)$.

Similarly, Base line median body weight $(50 \mathrm{~kg}, \mathrm{IQR}=45-57)$ was also increased by $5 \mathrm{~kg}$ after three year of initiation ( $55 \mathrm{~kg}, \mathrm{IQR}=50-63)$. Base line body weight and recent body weight $(55 \mathrm{~kg}, \mathrm{IQR}=49-63)$ had also a significant different with Wilcoxon Signed-Rank test $(\mathrm{p}<0.001)$ (Figure 3).

The total of 335 BMI value were available at base line. Median BMI at base line $\left(19.1 \mathrm{~kg} / \mathrm{m}^{2} ; \mathrm{IQR}=17.2-21.1\right)$ was increased by $1.7 \mathrm{~kg} / \mathrm{m}^{2}$ from recent BMI $\left(20.8 \mathrm{~kg} / \mathrm{m}^{2} ; \mathrm{IQR}=18.9-23.3\right)$. The average median of

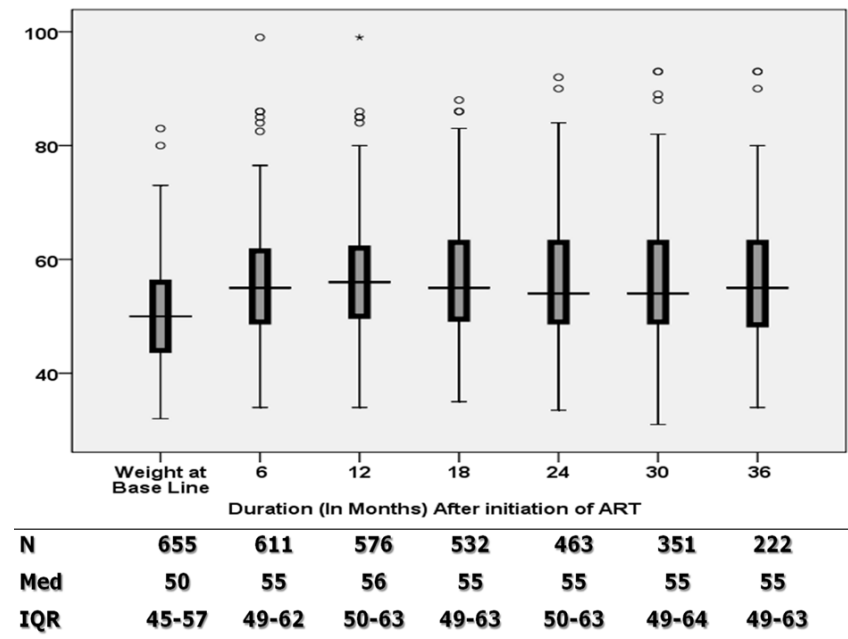

Figure 3: Three years of medan change of body weight in six monthly pattern after initiation of ART among PLWHA in Harar town, Eastern Ethiopia, March 2011.

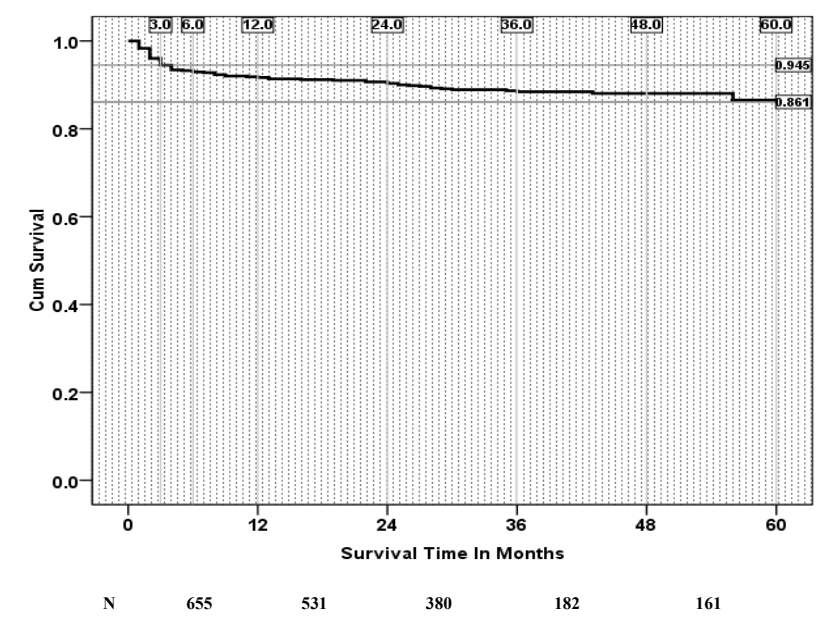

Figure 4: Survival probability of patients on ART starting from initiation of ART until the end of the study period among PLWHA, Harar town, Eastern Ethiopia, March 2011 
Citation: Digaffe T, Seyoum B, Oljirra L (2014) Survival and Predictors of Mortality among Adults on Antiretroviral Therapy in Selected Public Hospitals in Harar, Eastern Ethiopia. J Trop Dis 2: 148. doi: 10.4172/2329-891X.1000148

Page 5 of 7

recently measured hemoglobin $(\mathrm{n}=284 ; 13.3 \mathrm{gm} / \mathrm{dl} ; \mathrm{IQR}=12.0-14.5)$ was also differed by $1.7 \mathrm{gm} / \mathrm{dl}$ from hemoglobin at the ART initiation $(\mathrm{n}=346 ; 11.6 \mathrm{gm} / \mathrm{dl} ;$ IQR $(10-13)$. Both differences were statistically significant (Wilcoxon Signed-Rank test, $\mathrm{p}<0.001$ ).

\section{Predictors of survival}

During the follow up period, 74 (11.4\%) patients were deceased. The cohort was followed for 1913 Person-Years of observation. Total mortality rate over the follow up period was 3.9 per 100 person-years (74/1913). Mortality rates after first, second, third, and fourth years of follow up were $9.0(54 / 603), 9.8,(62 / 631), 8.1(72 / 894)$, and 5.1(73/1439) per 100 Person-Years, respectively. The survival probability at third month of ART initiation was $94.5 \%$. This proportion reduces to $92.9 \%$, at the sixth months and proceeded with $91.7 \%, 90.3 \%, 88.4 \%, 88.1 \%$, and $86.1 \%$ at one, two, three, four and the end of follow-up period, respectively (Figure 4 ).

Base line WHO clinical stages (Log rank, $p<0.001)$, functional status (Log rank, $p<0.001$ ), base line CPT (Log rank, p=0.03), and CD4 count (Log rank, $p<0.001$ ) were variables that showed the significant association with the survival of patients on ART with in Log rank test (Figure 5).

To reveal the independent predictors of early mortality after initiation of ART, univariate and multivariate Cox regression models were used. Among different base line variables incorporated in univariate Cox regression model, base line WHO clinical stage, CD4 count ( $<50$ vs. $\geq 50 \mathrm{cell} / \mu \mathrm{l})$, functional status of patient, base line opportunistic infection, base line OI prophylaxis, past body $10 \%$ weight

\begin{tabular}{|c|c|c|c|c|}
\hline Variable & $\mathbf{n}$ & $\begin{array}{c}\text { HR } \\
\text { Crude }\end{array}$ & $95 \% \mathrm{Cl}$ & $p$-value \\
\hline Age & 655 & 1.009 & $0.99-1.032$ & 0.425 \\
\hline $\begin{array}{l}\text { Sex } \\
\text { Male } \\
\text { Female }\end{array}$ & $\begin{array}{l}217 \\
438\end{array}$ & $\begin{array}{c}0.98 \\
1\end{array}$ & $0.63-1.66$ & 0.934 \\
\hline $\begin{array}{l}\text { WHO Clinical Status } \\
\text { Stage III and IV } \\
\text { Stage I and II }\end{array}$ & $\begin{array}{l}407 \\
248\end{array}$ & $\begin{array}{c}2.445 \\
1\end{array}$ & $1.386-4.311$ & 0.02 \\
\hline $\begin{array}{l}\text { Base Line functional Status } \\
\text { Working } \\
\text { Ambulatory } \\
\text { Bed Ridden }\end{array}$ & $\begin{array}{c}457 \\
159 \\
39\end{array}$ & $\begin{array}{c}0.148 \\
0.198 \\
1\end{array}$ & $\begin{array}{l}0.084-0.102 \\
0.263-0.385\end{array}$ & $\begin{array}{l}<0.001 \\
<0.001\end{array}$ \\
\hline $\begin{array}{l}\text { Base Line OI prophylaxis } \\
\text { No } \\
\text { Yes }\end{array}$ & $\begin{array}{c}37 \\
618\end{array}$ & $\begin{array}{c}2.876 \\
1\end{array}$ & $1.476-5.602$ & 0.002 \\
\hline $\begin{array}{l}\text { CD4 Count } \\
\text { CD4<50 cells } / \mu \mathrm{l} \\
\text { CD4 } \geq 50 \mathrm{cells} / \mu \mathrm{l}\end{array}$ & $\begin{array}{c}94 \\
561\end{array}$ & $\begin{array}{c}2.491 \\
1\end{array}$ & $1.502-4.129$ & $<0.001$ \\
\hline $\begin{array}{l}\text { Past } 10 \% \text { body weight loss } \\
\text { NO } \\
\text { Yes }\end{array}$ & $\begin{array}{c}575 \\
80\end{array}$ & $\begin{array}{c}4.708 \\
1\end{array}$ & $1.155-19.19$ & 0.031 \\
\hline $\begin{array}{l}\text { Occupation } \\
\text { Have a job } \\
\text { Job less }\end{array}$ & $\begin{array}{l}484 \\
171\end{array}$ & $\begin{array}{c}0.547 \\
1\end{array}$ & $0.342-0.875$ & 0.012 \\
\hline $\begin{array}{l}\text { Past opportunistic illness } \\
\text { No } \\
\text { Yes }\end{array}$ & $\begin{array}{l}198 \\
457\end{array}$ & $\begin{array}{c}1.653 \\
1\end{array}$ & $1.038-2.632$ & .037 \\
\hline
\end{tabular}

HR: Hazard Ratio, $n=$ Number of the patients

Table 2: Factors associated with early mortality according to Bivariate Cox regression analyses among PLWHA, Harar town, Eastern Ethiopia, March, 2011.
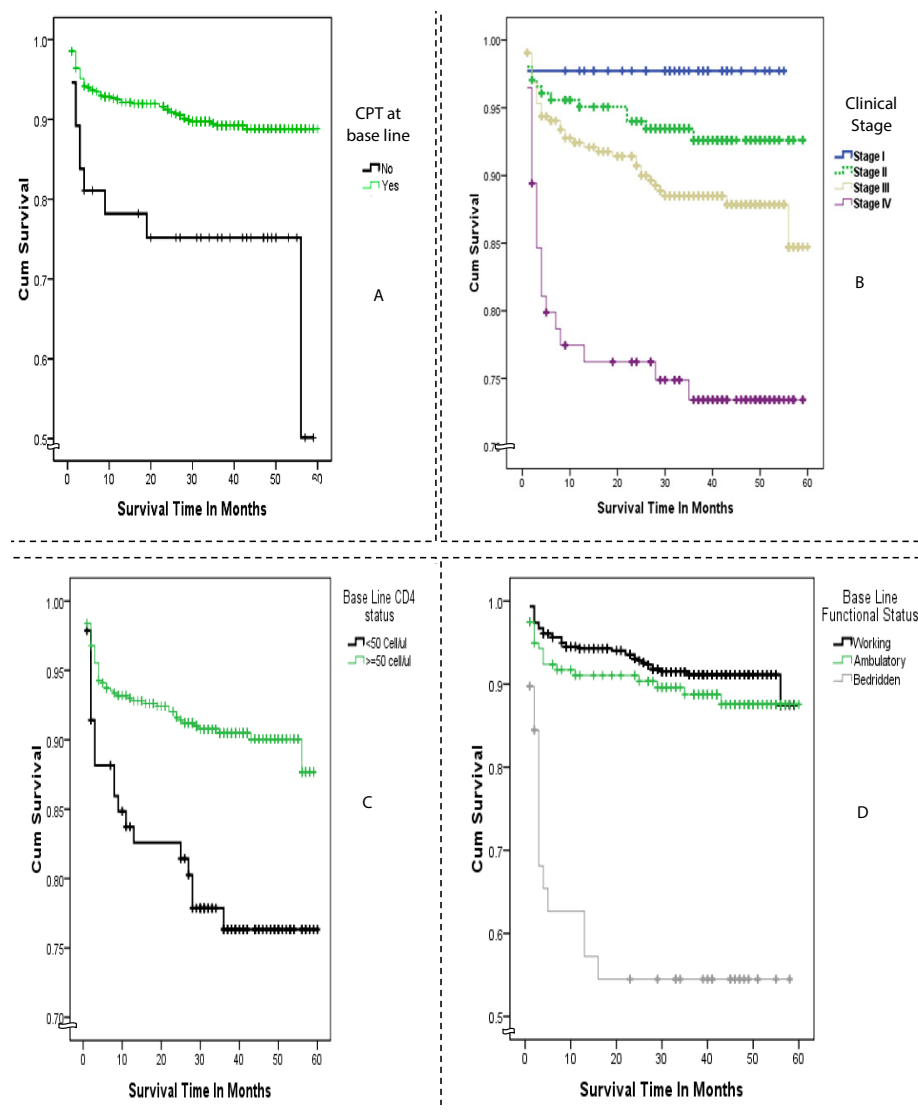

Figure 5: Kaplan Meier Survival plots for comparison of (A) Cotrimoxazole Prophylaxis Treatment (CPT), (Log rank test ,p=0.001) (B) WHO clinical stages, (Log rank test; $p=<0.001$ ); (C) CD4 Cell count status, (Log rank test, $p<0.001$ ); and (D) Functional status, (Log rank test; $p=<0.001)$ of the patients at base line among PLWHA Harar town, Eastern Ethiopia, March 2011. 


\begin{tabular}{|c|c|c|c|c|}
\hline Variable & $\mathrm{n}$ & $\begin{array}{c}\mathrm{HR} \\
\text { Adjusted }\end{array}$ & $95 \% \mathrm{Cl}$ & $p$-value \\
\hline Age & 655 & 1.014 & $0.990-1.039$ & 0.249 \\
\hline $\begin{array}{l}\text { Sex } \\
\quad \text { Male } \\
\text { Female }\end{array}$ & $\begin{array}{l}217 \\
438\end{array}$ & $\begin{array}{c}0.837 \\
1\end{array}$ & $0.497-1.411$ & 0.504 \\
\hline $\begin{array}{l}\text { WHO Clinical Stage } \\
\text { Stage III and IV } \\
\text { Stage I and II }\end{array}$ & $\begin{array}{l}407 \\
248\end{array}$ & $\begin{array}{c}2.134 \\
1\end{array}$ & $1.202-3.791$ & 0.01 \\
\hline $\begin{array}{l}\text { Base Line Ol prophylaxis } \\
\text { No } \\
\text { Yes }\end{array}$ & $\begin{array}{c}37 \\
618\end{array}$ & $\begin{array}{c}2.463 \\
1\end{array}$ & $1.255-4.834$ & 0.009 \\
\hline $\begin{array}{l}\text { CD4 Count } \\
\text { CD4<50 cells } / \mu \mathrm{l} \\
\text { CD4 } \geq 50 \text { cells } / \mu \mathrm{l}\end{array}$ & $\begin{array}{c}94 \\
561\end{array}$ & $\begin{array}{c}2.344 \\
1\end{array}$ & $1.404-3.913$ & 0.001 \\
\hline
\end{tabular}

Table 3: Cox model analysis of factors associated with early mortality among PLWHA, Harar town, Eastern Ethiopia, March 2011.

loss, and occupational status (have a job vs. jobless), showed significant association with early mortality after initiation of ART (Table 2). Age, sex, religion, marital status, educational status, sero-status disclosure, and substance use (alcohol, tobacco, and soft drug use) were found to be non-significant.

Different base line variables incorporated in Bivariate and Multivariate Cox regression model. After multivariate analysis, three baseline factors could be independently identified: WHO clinical stage III and IV (HR=2.134; 95\% CI=1.202-3.791, $\mathrm{p}=0.01)$; CD4 count lower than 50 cells $/ \mu \mathrm{l}(\mathrm{HR}=2.344 ; 95 \% \mathrm{CI}=1.404-3.913, \mathrm{p}=0.001)$; not taking Cotrimoxazole Prophylaxis Treatment $(\mathrm{CPT})$ at base line $(\mathrm{HR}=2.463$; 95\% CI=1.255-4.834, $\mathrm{p}=0.009$ ) (Table 3).

\section{Discussion}

In our study the survival probability of one year and at the end of the study period (five year) were $91.7 \%$ and $86.1 \%$, respectively. This finding largely deviated from the finding of other studies in Tanzania [8] and Cameroon [4]. Along with other methodological and study set up differences, the sample size, the longer follow-up period, time of ART initiation and treatment change may enlarge the difference of survival probability.

Additionally, Almost half of the deaths ( $\mathrm{n}=36,49 \%)$ occurred in the first 3 months of ART initiation. This higher mortality rate was similar with studies conducted in different Africa countries [5,7,9-13]. The early deaths may reflect the late initiation of ART with the advanced clinical stage and severely compromised status of CD4 cell counts $(<50$ cells/ $\mu \mathrm{l})$.

The CD4 cell count less than 50cells/ $\mu$ l was an independent predictor of early mortality among patients on ART in our study. Although there was difference in sample size and study methods, our finding is consistent with other studies conducted in Africa [5,9,13-15]. Hence, the ART should be initiated as early as possible in order to boost the prognosis and minimize the opportunistic infections.

The advanced WHO stages (stage III and IV) was also a major predictor of early mortality in present report. This finding is supported by other studies $[5,7,10,12,14]$. Consequently, it is unquestionable that ART should be started (initiated) as early as possible, prior to advanced clinical stages.

On the other hand, not taking of base line Cotrimoxazole prophylaxis treatment (CPT) was one of the predictors of early mortality in our study. This study was in agreement with other studies in Brazil [16], Uganda [17], and other parts of Ethiopia [13]. The prophylaxis should be given at the initiation of ART. This may reduce the violent effect of opportunistic infections on the mortality of PLWHA and improve the survival.

Antiretroviral treatment programs constitute a complex challenge for health systems, and virtually no evidence base exists to guide policy in low-income or middle-income countries [18]. Very high mortality rates recorded during the initial months of ART may reflect a high mortality rate among individuals who are eligible for ART but have yet to start treatment. This includes individuals enrolled in care who are awaiting treatment as well as those elsewhere in the healthcare system awaiting referral to HIV treatment services.

\section{Conclusion}

The increased availability of highly active antiretroviral therapy (HAART) treatment in resource-limited settings has brought benefits for people living with HIV/ AIDS, increasing hope resulting in lower mortality and morbidity rates. Treatment has proven to be highly costeffective in sub-Saharan Africa. Despite the improvement, however, mortality rates among patients treated in developing countries remain significantly higher than those observed in patients living in western countries. This is particularly the case in the first three months of therapy. It does not appear that this higher early mortality rate can be accounted for by the type of treatment available in resource-limited settings, especially since free-of-charge access to drugs has been demonstrated to be one of the determinants of treatment success.

\section{Recommendations}

1. The federal and regional health offices, in association with supporting stake holders, should endowed with longitudinal clinical and CD4 cell count monitoring to facilitate timely initiation of ART; and should strengthen long-term HIV care services for patients prior to ART eligibility.

2. Information and counseling on Cotrimoxazole prophylaxix treatment (CPT) should be routinely provided to all persons testing HIV positive. This should be done by health workers positioned at all level, particularly by providing preventive, care and treatment services to PLWHA.

3. Health workers and data clerks in ART center should be supported to appreciate the importance of properly recorded information.

4. There should be subsequent, preferably, prospective observational studies in the area of survival and predictors of mortality among PLWHA on ART.

\section{Acknowledgements}

I wish to express my special thanks to Haramaya University for funding the study.

\section{References}

1. HIVIAIDS Programme: Highlights 2008-09 (2010) Library Cataloguing-inPublication Data, WHO.

2. Towards universal access by 2010 (2006) How WHO is working with countries to scale-up. HIV prevention, treatment, care and support. WHO report, Geneva Switzerland.

3. Kloos H, Assefa Y, Adugna A, Mulatu MS, Mariam DH (2007) Utilization of antiretroviral treatment in Ethiopia between February and December 2006: spatial, temporal, and demographic patterns. Int J Health Geogr 6: 45.

4. Sieleunou I, Souleymanou M, Schönenberger AM, Menten J, Boelaert M (2009) Determinants of survival in AIDS patients on antiretroviral therapy in a rura centre in the Far-North Province, Cameroon. Trop Med Int Health 14: 36-43. 
Citation: Digaffe T, Seyoum B, Oljirra L (2014) Survival and Predictors of Mortality among Adults on Antiretroviral Therapy in Selected Public Hospitals in Harar, Eastern Ethiopia. J Trop Dis 2: 148. doi: 10.4172/2329-891X.1000148

5. Ferradini L, Jeannin A, Pinoges L, Izopet J, Odhiambo D, et al. (2006) Scaling up of highly active antiretroviral therapy in a rural district of Malawi: an effectiveness assessment. Lancet 367: 1335-1342.

6. Jerene D, Naess A, Lindtjørn B (2006) Antiretroviral therapy at a district hospita in Ethiopia prevents death and tuberculosis in a cohort of HIV patients. AIDS Res Ther 3: 10.

7. Jerene D, Endale A, Hailu Y, Lindtjørn B (2006) Predictors of early death in a cohort of Ethiopian patients treated with HAART. BMC Infect Dis 6: 136.

8. Johannessen A, Naman E, Ngowi BJ, Sandvik L, Matee MI, et al. (2008) Predictors of mortality in HIV-infected patients starting antiretroviral therapy in a rural hospital in Tanzania. BMC Infect Dis 8: 52.

9. van der Sande MA, Schim van der Loeff MF, Aveika AA, Sabally S, Togun T, et al. (2004) Body mass index at time of HIV diagnosis: a strong and independent predictor of survival. J Acquir Immune Defic Syndr 37: 1288-1294.

10. Mujugira A, Wester CW, Kim S, Bussmann H, Gaolathe T (2009) Patients with advanced HIV type 1 infection initiating antiretroviral therapy in Botswana: treatment response and mortality. AIDS Res Hum Retroviruses 25: 127-133.

11. MacPherson P, Moshabela M, Martinson N, Pronyk P (2009) Mortality and loss to follow-up among HAART initiators in rural South Africa. Trans R Soc Trop Med Hyg 103: 588-593
12. Etard JF, Ndiaye I, Thierry-Mieg M, Guèye NF, Guèye PM, et al. (2006) Mortality and causes of death in adults receiving highly active antiretroviral therapy in Senegal: a 7-year cohort study. AIDS 20: 1181-1189.

13. Abiyou Kifle Alemayehu, (2010) Disclosure among currently partnered HIV Positive Individuals and its Reliability; Zewditu Hospital; Addis Abeba; EPHA sponsored Master's Theses Extracts on HIVIAIDS.

14. Lawn SD, Harries AD, Anglaret X, Myer L, Wood R (2008) Early mortality among adults accessing antiretroviral treatment programmes in sub-Saharan Africa. AIDS 22: 1897-1908.

15. Abaasa AM, Todd J, Ekoru K, Kalyango JN, Levin J, et al. (2008) Good adherence to HAART and improved survival in a community HIVIAIDS treatment and care programme: the experience of The AIDS Support Organization (TASO), Kampala, Uganda. BMC Health Serv Res 8: 241.

16. Campos DP, Ribeiro SR, Grinsztejn B, Veloso VG, Valente JG, et al. (2005) Survival of AIDS patients using two case definitions, Rio de Janeiro, Brazil 1986-2003. AIDS 19 Suppl 4: S22-26.

17. Mermin J, Lule J, Ekwaru JP, Malamba S, Downing R, et al. (2004) Effect of cotrimoxazole prophylaxis on morbidity, mortality, CD4-cell count, and viral load in HIV infection in rural Uganda. Lancet 364: 1428-1434.

18. Bennett S, Boerma JT, Brugha R (2006) Scaling up HIVIAIDS evaluation. Lancet 367: 79-82. 